\title{
Grass Roots: the Development of Tennis in Britain, 1918-1978
}

\begin{abstract}
Most research on British tennis has focused on social exclusion at the tennis club, on its middle-class image, and on the 'shamateurism' of the pre-1968 era. This paper will chart the development of the sport at grass roots level. It will demonstrate that tennis in the workplace and public parks allowed lower-income families to play and that significant numbers did so in less formal settings than those overseen by regional Lawn Tennis Associations. It will suggest that a concentration on the wealthy south-east of England has distorted our impression of the sport itself and the 'average' club. Evidence from club histories, official handbooks, company archives and detailed local studies presents a very different picture from that of the suburban 'garden party'.
\end{abstract}

\section{Introduction}

'Lawn tennis can be played and enjoyed by boys and girls, men and women, of all degrees of excellence and of all ages'. (It) 'flourishes in the clubs, the schools and the public parks and ... can be played and enjoyed almost literally from the cradle to the grave. It is a recreational amusement played not too seriously but with just sufficient competitive interest to make it attractive. The great beauty of the game of lawn tennis is that, like cricket, it's a game for everyone'. i

This was the opinion of J.C. Smyth, tennis correspondent of the Sunday Times from 1946 to 1951. Perhaps these sentiments help to explain why it has received limited and patchy coverage from an academic community that has focused much of its attention on professional, competitive and elite aspects of sport. Since 1983, when the lack of any serious research on the development of tennis was adjudged 'one of the most baffling gaps in the entire literature of British sport history', things have improved marginally. ${ }^{\text {ii }}$ Most detailed studies in the past thirty years, however, have concentrated either on the tennis club as a cultural institution - on social exclusivity, on gender issues and the alleged importance of etiquette and fashion on the court - or the amateur /professional division in the elite game before the arrival of open tennis in 1968. ${ }^{\mathrm{iii}}$ Non-academic books on tennis in Britain, then and now, have dealt almost exclusively with Wimbledon and the careers of top tennis stars. ${ }^{\text {iv }}$ Well respected general histories of British sport in the twentieth century have continued to emphasise the middle or upper middle-class roots of tennis, harking back to the days when it was played on suburban and vicarage lawns. Even when opportunities for mass participation have been acknowledged, the image of posh tennis has lingered on, together with the suggestion that snobbishness within private clubs and the Lawn Tennis Association (LTA) have contributed in no small way to Britain's failure to find 'stars'. B But tennis is essentially for amateurs; like golf, there are very few opportunities for individuals to make a living on a limited professional circuit. Now that the British obsession with finding a successor to Fred Perry has finally been put to rest with Andy Murray's first Grand Slam title, it is perhaps time to reconsider the gentler backwaters of tennis as a recreational sport. Research undertaken into social 
exclusion and 'shamateurism' has left us with very little idea of how and where the grass roots game developed in the mid-twentieth century, and the role played by a variety of clubs. As far as tennis is concerned, we are still unclear 'about the organizations of sport at levels below national bodies'. ${ }^{\text {vi }}$

A brief history of grass roots tennis in the sixty years after 1918 illustrates its fluctuating fortunes. Recovering rapidly from wartime privations, it reached out into new communities during the inter-war years. This was the heyday of two under-researched sports spaces, public parks and workplaces, and 'tennis for the millions' was said to be the cry, both in Britain and America. ${ }^{\text {vii }}$ Some clubs suffered during the depression years of the early 1930s, and war ensured that others closed their gates for good. Although the immediate post-war period saw the formation of new clubs, particularly in schools, the sport was undermined from the mid-1950s by alternative leisure opportunities and increasingly poor facilities, and was overwhelmed by indifference, escalating costs and vandalism in the 1960s. Some clubs fought to balance the books by attracting more - and younger - members, and improving both the playing and the social environment; others were not equal to the task. Local authorities failed to maintain their courts and pleas to increase the development of parks tennis went unheeded, while workplace sport in general began to decline in a changing industrial landscape. By the early 1970s there was a danger that the 'everyone for tennis' optimism of the interwar years would revert to the 'anyone for tennis' model of the pre-1914 era. ${ }^{\text {vii }}$

To build a picture of the sport at its basic level requires a combination of official and 'amateur' sources. There are annual LTA handbooks to provide statistics, and county LTA histories to illustrate the development of tennis in specific regions. Local historians, club secretaries and long-standing members have used minutes and other documents, personal recollection, interviews, and newspapers to produce written accounts of their own associations, often to celebrate a centenary or important milestone. It might be argued that such longevity renders these histories atypical and there is a risk that the pride of their authors portrays them in rose-tinted lights. This is not evident from a sample of 34 clubs covering many regions of Britain: the research has failed to identify any special reasons for their survival, highlights many differences as well as similarities, and suggests that a 'warts-and-all' approach has been taken. Using all these sources together with material from company archives, this paper will demonstrate that tennis was not only for the privileged. Alongside the private clubs, many of which were far from exclusive, opportunities existed for lower income families to play in public parks and company sports grounds throughout the country in the middle decades of last century. As these facilities were lost, low-cost options narrowed. Although the maintenance of social exclusivity may have been of paramount concern to some private clubs, the research will also suggest that the struggle for survival was likely to be uppermost in the thoughts of many more. It will be asserted that focusing almost exclusively on upmarket metropolitan and suburban clubs - largely in the wealthiest region of the country, the south-east of England - has produced a distorted picture and re-enforced stereotypes that may be unrepresentative of other areas. As Mike Cronin has pointed out, 'in terms of making national conclusions we have to have nationally diverse empirical research at hand' and evidence from Scotland, the Midlands and the north of England will be given 
prominence. ${ }^{\mathrm{ix}}$ This is not to deny that there were issues of exclusivity and a 'them and us' culture at some tennis clubs but it should be acknowledged that such attitudes were not universal. ${ }^{\mathrm{x}}$ An initial overview of grass roots tennis in Britain from 1918 to 1978 will outline the development of the sport and attempt to quantify its changing fortunes.

\section{The Problem with Counting: Clubs and Members}

Little attempt has been made to establish the scale of grass roots tennis in Britain and the process is fraught with difficulty. Huggins and Williams, writing of the inter-war period, thought that club membership lists were of limited value in estimating participation because sports such as tennis, golf and bowls could be played outside formal associations. They reckoned that larger tennis clubs may have had between 50 and 100 members in the twenties and that the average was only 30 in the following decade but they give no indication as to how these figures were arrived at. ${ }^{\text {xi }}$ Even allowing for fluctuations in the inter-war period and, in particular, the economic downturn of the thirties, their figures seem rather low. Calculations by John Bale for the late 1970s were based on the number of clubs affiliated to the LTA, published yearly in the official LTA handbooks, but he pointed out that they give no details of size or active membership and are therefore crude indicators of the scale of tennis participation. ${ }^{\text {xii }}$ They are often the most reliable data sets available, however, and have to be used along with membership figures in the absence of anything better. LTA affiliation required a club to be 'an organisation of not less than twenty persons' but the present research has failed to uncover any as small as this. ${ }^{\text {xiii }}$ A sample of 16 clubs included only two with less than 100 members in the 1920s; none had less than 40 in the 1930s. It was not uncommon for clubs in cities and large towns to have 200-300 players and occasionally more. ${ }^{\text {xiv }}$

Another, and perhaps more thorny problem, concerns tennis outside the LTA structure. Insufficient attention has been paid to the amount of tennis taking place either in less formal settings such as public parks, or in clubs which chose not to affiliate. Neither is easy to quantify. One author clearly thought that 'the great bulk of tennis players belong to unaffiliated clubs' and suggested an estimate of 2 million taking part in these organisations, on park courts or in open spaces. ${ }^{\mathrm{xv}}$ There is no explanation of how he obtained this figure. Another, Andy Lusis, the historian of Nottinghamshire tennis, has painstakingly traced the history of nearly 500 tennis clubs in the county. He calculated that less than $20 \%$ of clubs were affiliated to the county LTA in 1928 but that this increased steadily after 1945; in adjacent Derbyshire, however, the affiliation rate was much higher, highlighting the difficulty of generalising from a single example. ${ }^{\text {xvi }}$ In Scotland, it was 'probably safe to assume' that there were between 50 and 100 nonaffiliated clubs towards the end of the twentieth century at a time when those in the Scottish LTA numbered less than 200. ${ }^{\text {xvii }}$ If this proportion had been similar in the period under review, 20-40\% of clubs in Scotland operated outside the official system. Applying these figures to the whole of Britain would suggest that the number of participants has been considerably under-estimated even before taking the 'casual' parks player into account.

Payment of a fee to the county LTA entitled a club to take part in officially 
sponsored leagues and cup competitions; it might therefore seem reasonable to suggest that those who failed to sign up saw no advantage in incurring additional costs because they were too small or lacking in good players to participate in tournaments. However, there were many competitive leagues outside the LTA structure in works sports associations, public parks and churches, and evidence from a sample of unaffiliated clubs shows that they were not necessarily small, short-lived or of little consequence. The author of the Aughton (Ormskirk, Lancashire) Lawn Tennis Club (LTC) centenary pamphlet describes it as 'very much a social club'. Although it had 150-200 members in the post-war period it only joined the league system in 1970 as, up till then, there had been 'resolute opposition to such a competitive approach'. xvii The same was true of Hale LTC which had declined to join the newly formed NE Cheshire League in 1954 despite boasting a membership of 200-250. Yet nearby Birkenhead and Bramhall Lane LTCs, both clubs of comparable size, affiliated to the Cheshire LTA in 1928 and 1948 respectively. ${ }^{\text {xix }}$ Scottish clubs Bearsden (Glasgow) and Braid (Edinburgh) had taken part in their respective regional LTA competitions from1904 though neither had more than 100 members at that time, but Welsh club Radyr LTC, with the same numbers, decided that 'league tennis was not in the best interests of the majority of the membership' and withdrew from its area league in 1927, only re-joining in $1973 .{ }^{\mathrm{xx}}$ In the south of England, Kent club Bromley Wendover, with only 57 members, entered the county leagues in the 1920s; Chesham Bois (Buckinghamshire) and Winchester (Hampshire), with twice as many members, eventually signed up in $1946 .{ }^{\mathrm{xxi}}$ Whether to affiliate or not was an individual club decision, apparently unrelated to size or locality but the existence of significant numbers of non-registered clubs renders the quantification of tennis a tricky exercise. For core numbers, we are forced back to the official LTA lists.

During the period under review, a figure of around 3,000 affiliated clubs has been suggested for the late 1930s; this was said to have risen to around 4,500 two decades later although this probably included school clubs which increasingly affiliated to the LTA in the post-war period. ${ }^{\text {xii }}$ A table published in Lawn Tennis and Badminton, 'the official organ of the LTA' in 1967 more or less supports these figures - 2,874 clubs in 1938, 2,731 in 1950 , and over 3,000 thereafter, peaking at 3,788 in $1959 .{ }^{\text {xiii }}$ Estimates for the 1970 s are agreed on a figure of roughly 2,500, the lowest number for 50 years. Furthermore, Bale considered that there were only 150,000 'serious participants', or roughly 60 per tennis club in $1979^{\text {xxiv }}$ : but who was being counted? Full adult members only? As tennis is a sport that can be played and enjoyed at very different levels of competence, should club size ignore juniors, students, 'afternoon', 'country' or 'winter' members? While some would have wished to play competitively and aspire to county standards, others took part for fun, exercise and sociability. Juniors, in particular, are the 'serious participants' of the future: by the 1960s, and often earlier, they could account for a significant proportion of club membership. Bearsden LTC had 116 juniors in 1964 from a total of $286(40 \%) ; 102$ members at Cullercoats LTC in Whitley Bay included 40 juniors in 1962; Blundellsands LTC in the Liverpool suburb of Crosby had 88 juniors in 1945 but only 48 seniors which suggests that the youngsters were playing an important role in keeping the club afloat in the difficult circumstances of war. ${ }^{\mathrm{xxv}}$ There are further examples of junior players saving clubs from extinction in the 1930s but also some evidence suggesting that under-18s were disadvantaged and discriminated against in their 
access to court time, and were tolerated rather than encouraged by adults in some clubs. ${ }^{\text {xxvi }}$ Some might argue that, in fairness, the substantially cheaper membership for juniors ought not to entitle them to equal playing opportunities. As ever, there is no onesize-fits-all answer; further research into tennis for young people in the mid-twentieth century might clarify the differing perspectives.

Assuming that the LTA handbooks present the most accurate picture of formal tennis participation, the following table has been produced using ten-year samples, and a lot of old-fashioned counting. The figures are close enough to validate previous estimates and demonstrate the general fluctuations in the health of club tennis over the midtwentieth century, a matter for discussion in the following section.

\section{Table 1. Tennis clubs affiliated to LTA (excluding schools)}

$\begin{array}{lccc} & \text { England } & \text { Wales } & \text { Scotland } \\ 1936 & 2181 & 73 & 228 \\ 1947^{*} & 1338 & 37 & \mathrm{nk} \\ 1956 & 3201 & 140 & 300 \\ 1966 & 2674 & 107 & 238 \\ 1976 & 2462 & 93 & 201\end{array}$

*Note: figures were not available for 1946

Sources: Lawn Tennis Association Official Handbooks

The issue of club size is less easy to resolve as many factors have to be considered. Some clubs artificially restricted entry, setting limits to numbers in different membership categories and operating waiting lists at stages in their development, sometimes with serious consequences. When Bearsden LTC introduced a waiting list for seniors in the early 1920s with no automatic right for juniors to transfer, a new local club poached many of its younger members. This suggests a serious lack of judgement as juniors had been admitted in unlimited numbers before the war, at a time when adults were restricted to $100 .{ }^{\text {xxvii }}$ Fluctuations in size were often arbitrary and unpredictable. One club historian remarked that 'there is usually a fairly substantial turnover in membership from year to year'; another noted a big turnover in top players during the fifties and sixties 'as young people moved jobs and girls developed careers' ${ }^{\text {xx }}$

Clubs could be, and usually were, affected by general economic conditions: a tennis club subscription is likely to have been an early casualty in any period of financial stringency. Improvements, deterioration or other physical changes to facilities could result in growth or decline in members: poor grass maintenance at Hale LTC in the early sixties led to a fall in adult membership, 'a similar decline in bar takings and social events' and a consequent rise in subscription rates. ${ }^{\text {xxix }}$ The changing demographics of local communities sometimes had an impact: Aughton LTC benefitted from its rise as a dormitory suburb of Liverpool and St Helens after 1945 but in the early seventies, Birkenhead LTC was 'being run on a shoestring' and only a fear of resignations prevented a rise in subscriptions 'in a district that was declining in affluence'. ${ }^{\mathrm{xxx}}$ Mergers 
with other local clubs raised numbers rapidly. Chapel Allerton (Leeds) had secured its future by amalgamating with a local rival in the 1940s; Busby in the Glasgow suburbs revived when a 1948 merger brought in over 100 new members. ${ }^{\text {xxi }}$ The age profile of a club could have disastrous consequences: Rutherglen in Glasgow went into decline in the early seventies when many team members retired or took up golf (there was no veterans tennis then). The Cardonald club, in another Glasgow suburb, had a thriving junior membership at this time but closed because it had too few seniors. ${ }^{\text {xxii }}$ It is clearly impossible to determine the size of the 'average' tennis club but, taking account of the substantial networks of informal organisations throughout Britain, it would seem that far more tennis was being played than we have been led to believe.

\section{An Overview of Grass Roots Tennis 1918-1978}

Evidence suggests that the sport of tennis was booming throughout the country in the 1920s. According to Andy Lusis, existing clubs in Nottinghamshire were 'bursting at the seams', and new clubs opening every year. Of the 270 for which there are formation dates, one-third were started in the 1920s. ${ }^{\text {xxiii }}$ Of 51 West of Scotland clubs still in existence in 2004, 14 (27\%) were founded in the 1920s, a higher number than any previous decade; similar growth could be found in Warwickshire with 27 new clubs (29\% of the 1960 total) formed in the twenties. ${ }^{\text {xxxiv }}$ Tennis 'took off' in the Colwyn Bay area of North Wales in the early 1920s and the North Wales LTA was founded in $1925{ }^{\mathrm{xxxv}}$ The number of clubs affiliated to Surrey County LTA rose from 114 in 1923 to 150 in 1926, and to 'well over 200' by 1937. In Durham and Cleveland, affiliated clubs increased from 23 in 1922 to 71 in $1930 .^{\text {xxxvi }}$

The economic problems of the early 1930s temporarily stalled this expansion. One-off entry fees at some of the more prestigious clubs were waived, and subscriptions were widely reduced; groundsmen had their hours and wages cut and coaches were let go. A variety of solutions were proposed at different clubs to boost numbers including Sunday opening, cheaper rates for combined husband/wife or family membership, or a broadening of the tennis club to include other sports. Squash courts were built at prestigious venues such as the Priory and Edgbaston clubs in Birmingham and Surbiton in Greater London but rejected as too costly at the Hazelwood club in Enfield. It settled instead for a putting green and 'ping pong' while Winchester Lawn Tennis and Croquet club added squash and bowls - but abandoned croquet. ${ }^{\text {xxxvii }}$

The war years brought a host of difficulties. Many clubs suffered financial problems as members were called up; some were only kept going by loans from those left at home, others were forced to close. (A particularly dramatic example was the Hollies club in Nottinghamshire which never recovered after a Lancaster bomber came down on its courts). ${ }^{\text {xxviii }}$ Tennis balls were in short supply, many courts became derelict or were ploughed up for use as allotments, and county activities were suspended. In spite of these problems, it was not a tale of unmitigated gloom. Land girls helped with ground maintenance at the Radyr LTC near Cardiff. Clarkston Bowling and Tennis Club in Glasgow kept up morale by hosting dances for servicemen and women on leave, as did Putney LTC in London. For others the war brought new members. Padgate Tennis and 
Bowling Club in Cheshire benefited from overseas military personnel stationed nearby, and the relocation of several government departments to the Colwyn Bay-Llandudno area of North Wales during the war was said to have raised standards in the area clubs. ${ }^{\text {xxix }} \mathrm{A}$ more controversial item was recorded in the history of the Winchester club. Although US service personnel supported fundraising bazaars and dances the club committee 'sadly agreed that black officers should not be admitted in order to conform with American custom,. ${ }^{\mathrm{xl}}$

The dislocation caused by war left tennis in a run-down state in the 1940s and recovery varied from place to place. In Durham \& Cleveland a number of well-known clubs disappeared and it was some time before others could restore their courts to playing condition. The historian of Surrey LTA, though acknowledging that many clubs had been forced to let their courts become overgrown in wartime, found it 'amazing' how quickly they were brought back into use. ${ }^{\text {xli }}$ In Essex, 66 clubs affiliated to the county LTA in 1947 had risen to 144 in 1950; in rural Shropshire the number of clubs doubled between 1946 and 1948. ${ }^{\text {xlii }}$ Although some struggled - and some failed - to replace members and repair grounds, new clubs sprung up, mergers were undertaken, and new coaching initiatives were introduced by county LTAs. Those with adequate funds took the opportunity of relaying courts instead of trying to repair them, as at Honor Oak in south London and Chapel Allerton in Leeds, where staff from the Bingley Research station (now the Sports Turf Research Institute) were called in to upgrade the surfaces. xliii Others, perhaps foreseeing the difficulty of hiring groundsmen in an increasingly competitive job market, replaced their grass with a variety of hard courts requiring less maintenance. Cullercoats LTC was not alone in having to fight with its local authority to get land released from agricultural use back to sport. ${ }^{\text {xliv }}$ In general, however, hopes were high; leagues re-formed and tennis regained its inter-war popularity.

The 1950s saw the sport reach its peak in terms of adult participation and for some clubs this was 'the golden decade', 'the halcyon days for tennis'. ${ }^{\text {xlv }}$ But problems were already on the horizon. Table 1 showed that the number of affiliated clubs in Britain fell by almost one-fifth in the ten years 1956-66, and club and county LTA histories also reflect the downturn in grass roots tennis throughout the country. In North Wales, tennis was said to be 'in a parlous state' by 1964 with ten clubs closing in the previous year. ${ }^{\text {xlvi }}$ In the Sheffield district, the 1960s ushered in 'years of some difficulty' for many clubs and problems for the local LTA. ${ }^{\text {xlvii }}$ The East Gloucestershire LTC in Cheltenham suffered a 'drastic fall in members' in 1957 and reduced its annual subscriptions in an effort to attract new recruits. Presumably this failed to improve matters as it was forced to advertise for members in the local papers in 1964, a fate that had befallen the Winchester club as early as 1952. . Giffnock tennis club, with a decline in membership and playing standards, although this is a case in which a strong junior section saved the situation. ${ }^{\text {xlix }}$ The club survived and is still flourishing today unlike Bellahouston LTC, a founder club of the West of Scotland LTA, forced to close in the late 1960s at the time of the M8 roadworks or Hillhead LTC, swallowed up by extensions to the BBC headquarters in Glasgow or Liberton LTC in Edinburgh, formed in 1883, but driven to extinction after repeated acts of vandalism. ${ }^{1}$ Throughout Britain, tennis courts disappeared under blocks of flats, car parks and 
playgrounds. Small private clubs were squeezed out of existence by the rising costs of court upkeep, increases in local authority rating assessment, compulsory land purchase orders and anti-social behaviour. Worse was to follow in the 1970s with competition from leisure centres and large multi-sport facilities but the decline in public parks courts was even more significant for the concept of 'everyone for tennis'.

\section{The Public Face of Grass Roots Tennis}

Although there are scattered references to tennis in public parks and open spaces, insufficient is known about this aspect of the sport. Dorothea Chambers, seven-time winner of the Wimbledon singles, referred to opportunities for playing in public parks as early as 1910. In larger urban areas some tennis courts had been constructed under park improvements schemes before the war - Manchester was said to have 46 courts in one venue alone. ${ }^{\text {li }}$ Seaside resorts often boasted a range of leisure facilities before 1914; an advertisement for Scarborough in 1913 listed three golf courses, five bowling greens, and twenty tennis courts as well as sailing and fishing. After the war, town councils were encouraged to promote themselves as tourist destinations as a result of the Health Resorts and Watering Places Act of 1921, and 'any place with a foothold in the tourist business' embarked on improvements to their amenities which often included tennis courts, putting and bowling greens, bandstands and paddling pools. ${ }^{\text {lii }}$ While these were aimed at visitors, they were obviously available to the local population as well, and numerous private clubs were formed to take advantage of these public facilities. For those who could afford it, many larger hotels catered for tennis holidays, some boasting their own professional coach in the summer season. Lowe's Lawn Tennis Annual for 1935 contains 39 pages of advertisements for 'the large number of fine hotels with facilities for tennis scattered about Britain, both round the coast and inland'. liii

Municipal provision continued to grow in the inter-war period, not only in Britain. In America parks tennis had taken off during the 1920s, and by 1930 the United States Lawn Tennis Association had organised National Parks singles championships for men and women. In Australia, many local councils built low maintenance asphalt courts in the 1930s, 'opening up to all' a sport that had been the preserve of the middle class. ${ }^{\text {liv }}$ Back home, the Sheffield Parks Association, set up in 1921, was responsible for building 'hundreds of "parks" courts' and the Star newspaper sponsored a cup competition. "The Scottish Public Parks LTA, was formed in 1932 by delegates from Edinburgh, Dundee and Glasgow, and moves were underway before 1939 to affiliate this body to the Scottish Lawn Tennis Association. In Edinburgh, the local Evening Dispatch trophy was competed for in the Meadows, a large open space near the centre of Edinburgh; hundreds came to watch the finals. Tennis courts in public parks were said to be packed: 'you had to book well ahead' lvi Costs were also reasonable: an hour's bowls or tennis was available for $2 \mathrm{~d}$ an hour at a time when the average wage was around $£ 315 \mathrm{~s}$. Converted to current prices, a tennis court could be hired for less then 50p. ${ }^{\text {lvii }}$

The case of Glasgow is particularly interesting. Glasgow Public Parks LTA, established in 1926, provided 'a huge amount' of tennis in the city and had many more courts than the private clubs. ${ }^{\text {lviii }}$ It affiliated to the West of Scotland LTA and entered 
teams in men's and women's leagues; it organised six divisions within the parks and played home and away matches. It was said that dozens lined the park courts to watch ordinary folk playing a match and possibly pick up tips, and that youngsters in particular learned to play the game this way, by watching. With no clubhouse or facilities for hospitality, there was no 'garden party image' here although the Association did celebrate its silver jubilee in 1951 with a dance at Glasgow City Chambers. But by the early 1970s it had ceased to exist. One reason suggested was that, from the early 1960s, many Park players 'went private', 'perhaps because it was cheaper'. lix This was certainly a period at which some local authorities were raising their charges. An article from The Scotsman in 1960 calculated that costs for municipal bowls and golf were now comparable with private clubs 'where facilities were infinitely superior' lx There is no reason to believe that tennis was any different. In 1972, the Edinburgh Evening News claimed that players on public bowling greens had more than halved in ten years and that 'the drift from public greens to private clubs has been going on for years'. 'xi For whatever reason, public tennis also became less popular and descriptions of people queuing to play on a park court became distant memories. The Leeds Parks Association, in which 'many people had their introduction to tennis', folded in the 1960s during what was perceived as the general decline in tennis and the courts fell into poor condition. ${ }^{\text {lxii }}$ Holt and Mason found that the numbers playing municipal tennis in Birmingham fell by 55\% from 1956 to 1964 and although they thought this primarily reflected a lack of coaching facilities it is possible that cost was another factor.

An important link in the above examples is that they all refer to northern areas of Britain. Although the south-east of England is supposed to be the natural heartland of tennis, no references to parks tennis have been discovered in county histories for Bedfordshire, Surrey and Essex. It is highly likely that parks associations existed in the south of England, as in other parts of the country, but more research is necessary to find out if public tennis was as significant here as in 'the north'. Once again, we are indebted to amateur historians like Andy Lusis for unearthing the sort of detailed information that the modern academic seldom has time to collect. Nottingham, further south than the other cities mentioned, had no public courts until 1922 when over 60 were built, with many sub-let to small clubs. After the war the sports ground became an industrial estate. The Nottingham Parks LTA, was formed at an alternative site in 1950, decades later than those further north, but appears to have closed at a later date in the fifties. ${ }^{\text {lxiv }}$ Given this record, it is perhaps unfortunate that John Bale chose Nottingham as a case study of urban tennis provision in 1979. By then, his view that conurbations were, without exception, lowly providers of opportunities for tennis may have been a sad, but accurate, reflection of what happened to parks courts but it was not representative of northern cities in the middle decades of the century. ${ }^{\text {xv }}$

It is increasingly difficult to reconcile statements that 'tennis was a suburban, Southern sport not much followed in the North outside of the leafy suburbs of the big cities' with evidence from the public parks. ${ }^{\text {xvi }}$ But until there is a detailed study of local authority provision throughout Britain, in small towns as well as cities, we are left with a significant gap in our understanding of how sport developed in the twentieth century and who played it. It is also worth remembering that former British men's number one player, 
Roger Taylor, who reached three Wimbledon semi-finals in the late 1960s and early 70s, was initially coached on the public courts of Sheffield by his mother, a woman with no background in tennis. He played in the Sheffield Parks League as a teenager and finally went to London to further his career at the age of 17, like Fred Perry before him. ${ }^{\text {lxvii }}$ Tim Henman may have emerged in the south from a privileged background but, with the inclusion of Andy Murray, that makes the score for successful British men: the North 3 the South 1.

\section{Tennis in the Workplace}

The popular and, one feels, somewhat contemptuous representation of the private tennis club is that of a 'marriage bureau' in leafy suburbia, dispensing strawberry teas on summer weekend afternoons. This may have been an accurate description of some clubs at some point in the twentieth century but it is far from universal. Detailed research during the post-war period when LTA affiliation was at its height shows that, for all English counties, an average of $30 \%$ of private clubs, nearly 1,000 in 1956, operated within the workplace. In one area - Derbyshire - this reached 58\%; half of all 36 English counties recorded above average numbers of works tennis clubs in that year. Ten years later, at a time when municipal tennis was already in decline, figures for workplace clubs were being maintained. Given that an affiliated club had to have at least 20 members, a bare minimum of 20,000 were playing tennis on company courts during this period. This figure could be considerably higher when smaller tennis sections of works sports clubs and other non-unaffiliated groups are included. It was only in the 1970s that affiliations fell to around $20 \%$ of total LTA clubs, a level that continued into the 1980 s. $^{\text {lxviii }}$

The great boom in company tennis probably occurred during the inter-war period but a few firms had introduced it earlier. Roger Munting's article on industrial capitalism identifies several firms in the Norwich area that offered tennis before 1914, and Lever Bros. Port Sunlight works in Cheshire as well as Cadburys Bournville factory had constructed tennis courts as early as 1897 and 1904 respectively. ${ }^{\text {lxix }}$ The author of the Bournville Athletic Club 50 th anniversary pamphlet, written in 1946, singled out this early provision of tennis facilities for special praise: 'The Bournville Athletic Club and its sister organisation, the Girls' Athletic Club, may claim to have brought tennis within the reach of the Bournville community at a date when industrial workers who played tennis were very few indeed'. 'Ixx In 192636 all-male and all-female tennis teams played 233 competitive matches, not counting the 'hundreds of casual tennis games'. ${ }^{x x i}$ By the 1930s Bournville boasted 60 tennis courts, was affiliated to the Warwickshire LTA and took part in the Birmingham Tennis League. And lest we cynically sneer that it was probably members of the office staff and management who monopolised the courts, this was not the intention: 'Clubs and Societies are voluntary associations of interested employees who conduct their own affairs through elected committees. Membership is open to all employees without distinction and in some cases to their families and friends'. lxxii

Bournville was a company village and its scale is not typical of the workplace club. Further research, however, confirms a significant number and variety of employer 
providing opportunities to play tennis, not only for leisure but for competition. Clark's Thread Mills in Linwood, near Glasgow, ran the Anchor Recreation Club for employees from 1923 until the firm closed in 1983, and in the 1920s two female employees won the Scottish Welfare Tennis Association open tournament. ${ }^{\text {lxxiii }}$ The John Lewis Partnership took part in the West End Lawn Tennis Association leagues, battling opponents from firms such as Harrods, Lyons and Nestle. Miss F. Haldane, a clerical worker at their Peter Jones department store in London, had 'the great honour of being accepted as a competitor in the Open Championships at Wimbledon' in 1923, having won the retailers' ladies' singles for the fourth successive year. ${ }^{\text {lxxiv }}$ In Hull an association of 52 firms representing 30,000 employees organised sections for tennis, angling, billiards, ladies' golf and cricket. ${ }^{l x x}$

Works clubs of every description can be found in Nottinghamshire: at hospitals and colleges of education, police forces and RAF stations, co-operative societies and political organisations, and a wide range of factories including everything from heavy engineering and machine tool plants to ropeworks and hosiery companies. Figures calculated from LTA handbooks show that Nottinghamshire averaged 46 affiliated clubs over the period 1936 - 1976, nearly 40\% of which were works clubs. Many more operated outside the official system, organising their own leagues and tournaments, and foremost amongst these were the regional colliery and miners' welfare clubs. The Mining Industry Act of 1920 had created a Welfare Fund 'to be applied for purposes connected with the social wellbeing, recreation and conditions of living of workers in and about coal mines' and many areas chose to support sports facilities. ${ }^{\text {lxvi }}$ The Collieries Alliance League in Nottinghamshire ran mixed sex and men-only tennis leagues and knock-out tournaments from the early 1920s to 1969 although there are no records to indicate what category of worker took part in these competitions. Twelve different colliery or welfare clubs won these competitions over 45 years but a further 24 were known to exist. Most had two or three courts and closed in the 1960s; a few lasted into the 1980s. ${ }^{\text {lxxvii }}$ It is unlikely that Nottinghamshire was alone among the mining counties in organising colliery leagues but further research in areas such as Durham, Yorkshire or Central Scotland would be useful for comparison. The LTA handbook for 1956 indicates that there were at least 75 affiliated working men's club and miner's welfare tennis groups throughout the north of England but thirty years later, with large-scale colliery closures and alternative leisure options, there were only seven.

Workplace tennis was also a feature of the south of England. There may have been more clubs in banking, retail and public service and a smaller percentage of company sports clubs overall but in only a handful of areas did the figure fall below $20 \%$ of the total. Table 2 shows the counties with the highest and lowest percentage of works clubs - the Midlands are strongly represented in the first column, as befits the industrial heartland of England, the rural south coast predictably has the fewest. Even in the leafy Home Counties - Berkshire, Hertfordshire and Middlesex - nearly a quarter of tennis clubs were workplace based. These figures over a 20 -year period demonstrate the importance of the workplace tennis club throughout Britain. 


\section{Table 2 Works Clubs as Percentage of Total - Highest and Lowest Ten Counties}

$\begin{array}{lllr}\text { Derbyshire } & 58 & \text { Sussex } & 5 \\ \text { Warwickshire } & 45 & \text { Dorset } & 14 \\ \text { Bedfordshire } & 44 & \text { Cheshire } & 15 \\ \text { Gloucestershire } & 44 & \text { Devon } & 15 \\ \text { Nottinghamshire } & 43 & \text { Cumbia } & 18 \\ \text { Cambridgeshire } & 43 & \text { Somerset } & 19 \\ \text { Suffolk } & 43 & \text { Shropshire } & 21 \\ \text { Kent } & 42 & \text { Berkshire } & 24 \\ \text { Leicestershire } & 39 & \text { Hertfordshire } & 24 \\ \text { Wiltshire } & 37 & \text { Middlesex } & 24\end{array}$

Source: Lawn Tennis Association Handbook, 1956

The multiple motivations behind company provision of sports facilities - the improvement of health and physical fitness in order to increase productivity, the attraction and retention of staff or, in the opinion of one Sheffield steel magnate, 'the best antidote to revolution and revolutionary ideas', have been discussed elsewhere. ${ }^{\text {lxxviii }}$ Government and employers in the interwar years were certainly of the opinion that the provision of sports facilities promoted class collaboration rather than confrontation and, by this period, classic Victorian notions of rational recreation, middle-class philanthropy and paternalism had faded into the background. Company sports clubs were, in any case, a mixture of white and blue collar personnel and this is summed up well in the Bournville $50^{\text {th }}$ anniversary pamphlet:

We have helped to extend the playing of once-exclusive games - tennis, rugby, badminton, and squash - to the general public; and we have pursued our activities in an essentially democratic way: office and factory employees and members of the Firm, management and workers, brilliant sportsmen and novices, meet in our Club as equals. ${ }^{1 \times x i x}$

As in the public parks, the costs of playing works sport were often ridiculously cheap with equipment usually provided free or for a nominal sum. Annual membership of the Bournville Athletic Club remained at 6s, or £5 in current prices, from 1926 to the post-war era. A 1938 survey in Industrial Welfare noted that, for about 3d a week usually deducted from the wage packet at source, many employees had access to a wealth of facilities, including tennis courts. ${ }^{\mathrm{lxxx}}$ The John Lewis Partnership, employing around 30,000 staff by 1970, had its own 'country clubs' offering a wide range of outdoor activities such as cricket, football, hockey and tennis. Full annual membership cost one day's pay up to a limit of $8 \mathrm{gns}$ (c.£115) in 1962; the maximum amount payable for family membership including husbands/wives and children was $12 \mathrm{gns} .{ }^{\text {lxxi }}$ Other firms negotiated playing facilities for their staff at local clubs. IBM arranged for 70 of its employees to receive a $25 \%$ discount on fees at the Winchester Tennis and Squash Club in 1965; this was reduced to $20 \%$ in 1974 . Access to works clubs was sometimes open to non-employees as well, opening up opportunities for the wider community. Weir 
Recreation, the sports club of Weir Pumps Limited in the West of Scotland, offered associate membership for $12 \mathrm{~s} 6 \mathrm{~d}$ in 1948 (less than $£ 15$ ). ${ }^{\text {lxxxii }}$

It is not that we are unaware of company sport provision, but we seem to have forgotten how important it could have been for a sizeable section of the population and how many opportunities it offered lower income households to take part in activities that might have been beyond their means. Not all employers, however, were as enthusiastic as John Spedan Lewis, a keen sportsman, son of the founder of the original John Lewis department stores, and intimately connected with the business from the first decade of the twentieth century until his retirement in 1955. Strongly influenced by the Cadbury family, his motivation was said to be 'a desire to give his father's employees the chance to do things their station in life and lack of money wouldn't ordinarily allow them'. Fifty years after his death, the John Lewis Partnership 'is now alone in the scale and range of subsidised facilities for its employees'.

\section{Conclusion}

There are still many issues to investigate in grass roots tennis. The story of the ordinary tennis club - its lifecycle, its economic viability, and its place in the local community has yet to be written. What is required is a prosopographical analysis or collective biography of tennis similar to that undertaken for golf before 1914. ${ }^{\text {lxxiii }}$ Although evidence from club histories has been used to trace the development of the sport in the mid-twentieth century, this paper has been more concerned with forms of tennis that have been largely overlooked. It has also concentrated on areas of Britain outside London and the south-east: what is typical there may not be replicated further north. This may be illustrated with reference to the 1920s female tennis star, Suzanne Lenglen. A trendsetter in fashion for women, "The Lenglen Bandeau", two yards of coloured silk wrapped round the head, was de rigeur for chic women on and off the court. ${ }^{\text {,xxxiv }}$ No doubt this was the case in Wimbledon and other wealthy suburbs but are we sure this style was copied elsewhere? Possibly not in Scotland, where it is singularly absent from photographs of cup-winning ladies' teams in the mid-1920s (although the lady herself played an exhibition at Hampden Park in 1927 in front of 8,000 spectators), nor amongst the female members of the colliery leagues. ${ }^{\text {lxxxv }}$ We need more visual evidence of tennis for the masses from the inter-war period.

It is also unlikely that Grand Draws for club funds at metropolitan clubs, where bazaars, bridge, and dinner dances were popular, would include prizes such as a heifer calf, a chicken, a duck and 50 cigarettes, as presented at Baschurch LTC in rural Shropshir in 1949. It is equally unlikely that members of Queen's, Roehampton or the All-England Club would be enthusiastic about a 'Fish and Chip' tournament, a highlight of the year at Cullercoats in Northumberland in the 1970s, involving 'mixed doubles with a fish and chip supper'. ${ }^{\text {lxxvi }}$ Tennis and tennis clubs in Britain came in many forms.

Notes 
${ }^{\mathrm{i}}$ Smyth, Lawn Tennis, 233-4.

ii Baker, 'The State of British Sport History', 64, n.67.

iii See, for example, Lake, 'Gender and Etiquette', and 'Social Exclusion'; Jefferys, 'Fred Perry', 'The Heyday of Amateurism', and 'The Triumph of Professionalism'; Brasher, 'Traditional Versus Commercial Values in Sport'.

iv Non-academic books range from Macauley and Smyth, Behind the Scenes and Tingay, History of Lawn Tennis to the more recent Henderson, The Last Champion and the All-England Club's Centre Court.

${ }^{v}$ Earlier general sport texts include Hargreaves, Sporting Females; Polley, Moving the Goalposts; and Hill, Sport, Leisure and Culture. Helen Walker, in one of the few detailed accounts of tennis in Britain, gives a number of examples of where the game was played, yet manages to leave the impression that tennis for the 'toffs' at the prestigious Queen's Club in London was typical. Walker, 'Lawn Tennis', 249-256. For theories on the attitudes of the LTA and sports clubs, see Lake, 'Social Exclusion in British Tennis'.

vi MacLean, 'Evolving Modern Sport', 49.

vii Sheffield and District LTA Centenary, 17.

viii Both phrases are used by historian Andy Lusis; Lusis, Tennis in Robin Hood's County, 29, 66. Jeff Hill also quotes the saying 'anyone for tennis?' and its connotation with social privilege and the leisured life-style. Hill, Sport, Leisure \& Culture in Twentieth-Century Britain, 36.

ix Cronin, 'What Went Wrong with Counting?', 400.

${ }^{\mathrm{x}}$ For an outline and discussion of social capital theory, see Coalter, 'Sports Clubs, Social Capital and Social Regeneration', 539-544.

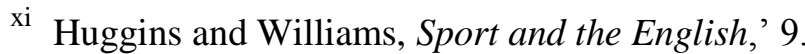

xii Bale, Sport and Place, 94-5.

xiii LTA, LTA Official Handbook, Rule 39, 1956.

xiv In the period 1945-55, Clarkston Tennis Club in Glasgow had 232 members, the Jesmond club in Newcastle 295, Priory in Birmingham c.700, Leicestershire Lawn Tennis Club 420, and Felixstowe 256.

xv Rivers, The Sports Book, vol.2, 227.

${ }^{x v i}$ Lusis, Tennis in Robin Hood's County, 66-7, and correspondence with the author, 21 July 2011.

${ }^{x v i i}$ Robertson, Tennis in Scotland, 66. 
xviii

Hargreaves, Aughton LTC Centenary, n.p.

xix Nelson, History of Hale LTC, 27; Cook, Birkenhead LTC Ltd, 5; Gare, Bramhall Lane LTC, n.p.

xx Bearsden LTC, 2; Borthwick, Braid Tennis Club, 16; Clark, Radyr LTC, 6.

xxi Lynch, Centenary History of Bromley Wendover LTC, 15-17; Chesham Bois Lawn Tennis and Squash Club, n.p.; Mussell, Winchester Tennis and Squash Club, 10.

xxii Walker, 'Lawn Tennis,' 250; Holt, Sport and the British, 127; Jefferys, 'The Heyday of Amateurism,' 2245; Holt and Mason, Sport in Britain, 54.

xxiii Lawn Tennis and Badminton, May 1967, 128.

xxiv Ibid.; Bale, Sport and Place, 6, 94.

xxv Bearsden LTC, 17; Angus, Cullercoats LTC, 39; Blundellsands LTC, n.p.

xxvi Lusis, Tennis in Robin Hood's County, 42; Lake, 'Social Exclusion in British Tennis', 136-7.

xxvii Bearsden LTC, 5-6.

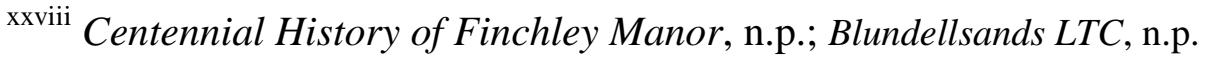

xxix Nelson, History of Hale LTC, 21.

xxx Hargreaves, Aughton LTC Centenary, n.p.; Cook, Birkenhead LTC Ltd, 27.

xxxi Chapel Allerton Lawn Tennis and Squash Club, n.p.; Hunter, 100 Years of Tennis, 79.

xxxii Ibid., 147, 184.

xxxiii Figures calculated from Lusis, 70-119.

xxxiv Figures calculated from Hunter, 100 Years of Tennis, 63-178 and from Warwickshire Lawn Tennis Association Handbooks.

xxxv Jones, Tennis in North Wales, 10.

xxxvi Paish, Surrey County LTA, 4-5; History of Durham \& Cleveland LTA, 1-2.

xxxvii Edgbaston Priory Club, n.p.; Surbiton LTC, n.p.; Hazelwood LTC, n.p.; Mussell, Winchester Tennis and Squash Club, 8. 
xxxviii Lusis, Tennis in Robin Hood's County, 52.

xxxix Clark, Radyr LTC, 9; Cheshire County LTA, 37; Jones, Tennis in North Wales, 19;

Clarkston Bowling and Tennis Club, 21; Putney LTC Centenary Special, 9.

${ }^{\mathrm{xl}}$ Mussell, Winchester Tennis and Squash Club, 9.

xli History of Durham \& Cleveland LTA, 2; Paish, Surrey County LTA, 13.

xlii Tennis in Essex, 6; Henshaw, Passing Shots, 43.

xliii Alexander, History of Honor Oak, 116; Chapel Allerton Lawn Tennis and Squash Club, n.p.

xliv Angus, Cullercoats LTC, 21.

${ }^{x l v}$ Costelloe, History of Catford Wanderers, 7; Reigate LTC, 10.

xlvi Jones, Tennis in North Wales, 28.

xlvii Sheffield and District LTA Centenary, 26.

xlviii Rockett, East Gloucestershire Tennis Club Centenary; Mussell, Winchester Tennis and Squash Club, 13.

xlix $\underline{\text { www.giffnock-ltc.co.uk }}$

${ }^{1}$ Hunter, 100 Years of Tennis, 184, 187; Edinburgh Press Cuttings, 1973.

li Chambers, quoted in Walker, Lawn Tennis, 251; ibid.

lii Anderson \& Swinglehurst, The Victorian and Edwardian Seaside, 16; Durie, Scotland for the Holidays, 194.

liii Lowe, Lowe's Lawn Tennis Annual, iii-xli.

liv Davenport, 'Tennis', 1169; Stell, Half the Race, 74.

lv Sheffield and District LTA Centenary, 17.

${ }^{\text {lvi }}$ Robertson, Tennis in Scotland, 173; Edinburgh Press Cuttings.

lvii Jones, Workers at Play, 14.

lviii Hunter, 100 Years of Tennis, 190.

lix Ibid., 191-2. 
1x The Scotsman, 23 November 1960.

1xi Edinburgh Evening News, 20 July 1972.

lxii Chapel Allerton Lawn Tennis and Squash Club, n.p.

1xiii Holt and Mason, Sport in Britain, 54.

lxiv Lusis, Tennis in Robin Hood's County, 31—2, 99.

lxv Bale, Sport and Place, 99, 106.

${ }^{1 x v i}$ Holt, 'Heroes of the North', 160.

lxvii The Star (Sheffield), 9 June 2011. I am grateful to Wray Vamplew for this information.

lxviii Figures calculated from LTA Handbooks.

Ixix Munting, 'The Games Ethic and Industrial Capitalism'; Lever Bros. archive, Progress, 1900, 382-3; Cadbury Archive: Bournville Athletic Club. 1896 and All That: 50 Years of the Bournville Athletic Club, 1896-1946, 7.

${ }^{1 x x}$ Ibid.

1xxi Cadbury Archive: Bournville: Work and Play, 1926.

Ixxii Cadbury Archive: Bournville Works and Its Institutions, 1946.

lxxiii Hunter, 100 Years of Tennis, 63.

lxxiv The Gazette, John Lewis Partnership, 1 July 2000.

lxxv Jones, Workers at Play, 70.

lxxvi Ibid., 73.

lxxvii Figures calculated from Lusis, Tennis in Robin Hood's County.

Ixxviii See, for example, Munting, 'The Games Ethic and Industrial Capitalism'; Jones, Workers at Play (quote, 180); Long, The Rise and Fall of the Healthy Factory.

lxxix Cadbury Archive: 1896 and All That, 20.

lxxx Jones, Workers at Play, 70.

lxxxi G.H. Lee Chronicle 105, John Lewis Partnership, 23 Feb. 1962. 
1xxxii Mussell, Winchester Tennis and Squash Club, 17; Hunter, 100 Years of Tennis, 168.

lxxxiii Vamplew, Sharing Space. For discussion of prosopography see Erard and Bancel, 'Prosopographical analysis of sports elites'.

lxxxiv Brasher, 'Traditional Versus Commercial Values in Sport', 202.

lxxxv Robertson, Tennis in Scotland, 116, 122.

lxxxvi Henshaw, Passing Shots; Cullercoats LTC, 50.

\section{References}

Alexander, M.B. A History of Honor Oak Cricket and Lawn Tennis Club - Centenary 18661965. The Club, 1965.

All-England Lawn Tennis Club, John Barrett and Ian Hewitt. Centre Court: the Jewel in

Wimbledon's Crown. London: Vision Sports, 2010.

Anderson, Janice and Edmund Swinglehurst. The Victorian and Edwardian Seaside. London:

Hamlyn Publishing, 1978.

Angus, Eric. Cullercoats Lawn Tennis Club, 1893-1993. The Club, 1993.

Baker, William J. 'The State of British Sport History'. Journal of Sport History 10, no.1 (1983): 53-66.

Bale, John. Sport and Place: A Geography of Sport in England, Scotland and Wales. London:

Hurst, 1982.

Bearsden Lawn Tennis Club 1887-1987. The Club, 1987.

Blundellsands Lawn Tennis Club Centenary 1880 - 1980. The Club, 1980.

Borthwick, A. Braid Tennis Club: a Centenary History 1890-1990. The Club, 1990.

Brasher, Kate. 'Traditional Versus Commercial Values in Sport: The Case of Tennis'. In The

Politics of Sport, ed. Lincoln Allison, 198-215. Manchester: Manchester University Press, 1986.

Chapel Allerton Lawn Tennis and Squash Club1880 - 1980.. The Club, 1980.

Chesham Bois Lawn Tennis and Squash Club 1908-2008. The Club, 2008.

Cheshire LTA. Cheshire County Lawn Tennis Association Centenary 1895-1995.

Clark, Guy. Radyr Lawn Tennis Club, 1914 to 1989. The Club, 1989.

Clarkston Bowling and Tennis Club Jubilee History 1909-1959. The Club, 1959.

Coalter, Fred. 'Sports Clubs, Social Capital and Social Regeneration: "ill-defined interventions with hard to follow outcomes"?' Sport in Society 10, no.4 (2007): 537-559.

Coles, Marian. Felixstowe Lawn Tennis Club 1884-1984. The Club, 1984.

Cook, K. Clifford. Birkenhead Lawn Tennis Club Limited 1892-1992. The Club, 1992.

Costelloe, Denis. A History of Catford Wanderers Lawn Tennis Club 1914-1998. The Club, 1998. Cox, Peter. Spedan's Partnership; the Story of John Lewis and Waitrose. Labatie Books, 2010.

Cronin, Mike. 'What Went Wrong with Counting? Thinking about Sport and Class in Britain and Ireland'. Sport in History 29, no.3 (2009): 392-404.

Davenport, Joanna. 'Tennis'. In International Encyclopedia of Women and Sports, Vol. III, eds. Karen Christensen, Allen Guttmann and Gertrud Pfister, 1168-1173. New York: MacMillan, 2001.

Durie, Alastair J. Scotland for the Holidays: A History of Tourism in Scotland c1780-1939. East Linton: Tuckwell, 2003.

Durham \& Cleveland LTA. History of Durham \& Cleveland Lawn Tennis Association 18951999. 
Edgbaston Priory Club: Centenary Year 1875-1975. The Club, 1975.

Edinburgh Press Cuttings, vol.1, 1938-1992.

Erard, Carine and Nicolas Bancel. 'Prosopographical analysis of sports elites: overview and evaluation of a seminal study'. International Journal of the History of Sport 24, no.1 (2007): 67-79.

Essex LTA. Tennis in Essex: the First 100 Years, 1895-1995.

Finchley Manor Lawn Tennis Club. A Centennial History of Finchley Manor Lawn Tennis and Squash Rackets Club 1881-1981. The Club, 1981.

Gare, T. Bramhall Lane Lawn Tennis Club: a story of more than 90 years of tennis. The Club, 2000.

Hargreaves, Ian. Aughton Lawn Tennis Club Centenary 1892-1992. The Club, 1992.

Hargreaves, Jennifer. Sporting Females: critical issues in the history and sociology of women's sport. London: Routledge, 1994.

Hazelwood Lawn Tennis and Squash Club 1909-2009. The Club, 2009.

Henderson, Jon. The Last Champion: the Life of Fred Perry. London: Yellow Jersey, 2010.

Henshaw, John. Passing Shots: Shropshire Tennis, 1885-2003.

Hill, Jeffrey. Sport, Leisure \& Culture in Twentieth-Century Britain. Basingstoke: Palgrave, 2002.

Holt, Richard. 'Heroes of the North: sport and the shaping of regional identity'. In Sport and Identity in the North of England, eds. Jeff Hill and Jack Williams, 137-164. Keele: Keele University Press, 1996.

Holt, Richard and Tony Mason. Sport in Britain 1945-2000. Oxford: Blackwell, 2000.

Huggins Mike and Jack Williams, Sport and the English 1918-1939. London: Routledge, 2006. Hunter, Myra. 100 Years of Tennis in the West of Scotland, 1904-2004. Glasgow: West of Scotland Lawn Tennis Association, 2004.

Jefferys, Kevin. 'Fred Perry and British Tennis: "Fifty Years to Honor a Winner"'. Sport in History 29, no.1 (2009): 1-24.

Jefferys, Kevin. 'The Heyday of Amateurism in Modern Lawn Tennis'. International Journal of the History of Sport 26, no.15 (2009): 2236-2252.

Jefferys, Kevin. 'The Triumph of Professionalism: The Road to 1968'. International Journal of the History of Sport 26, no.15 (2009): 2253-2269.

Jesmond Lawn Tennis Club 1883-1983. The Club, 1983.

Jones, Elwyn S. Tennis in North Wales. Ruthin: the author, 2000.

Jones, Stephen G. Workers at Play: A Social and Economic History of Leisure 1918-

1939.London: Routledge \& Kegan Paul, 1986.

Lake, Robert J. 'Social Exclusion in British Tennis: A History of Privilege and Prejudice.' PhD

diss., Brunel University, 2008.

Lake, Robert J. 'Gender and Etiquette in British Lawn Tennis 1870-1939: a Case Study of

"Mixed Doubles". International Journal of the History of Sport 29, no.5 (2012): 691-710.

Langhamer, Claire. Women's Leisure in England 1920 - 60. Manchester: Manchester University

Press, 2000.

Lawn Tennis Association. Lawn Tennis Association Official Handbooks, 1936-76.

Leicestershire Lawn Tennis Club: Histories and Notes 1878-1978. The Club, 1978.

Long, Vicky. The Rise and Fall of the Healthy Factory: the Politics of Industrial Health in

Britain, 1914 -60. Basingstoke: Palgrave Macmillan, 2011.

Lowe, F. Gordon, ed. Lowe's Lawn Tennis Annual 1935. London: Eyre \& Spottiswoode, 1935.

Lusis, Andy. Tennis in Robin Hood's County: The Story of Tennis Clubs in Nottinghamshire.

Nottingham: the author, 1998.

Lynch, Phil. Centenary History of Bromley Wendover Lawn Tennis Club 1906-2006. The Club, 2006. 
Macauley, Duncan and John Smyth. Behind the Scenes at Wimbledon. London: Collins, 1965.

MacLean, Malcolm. 'Evolving Modern Sport'. Journal of Sport History 35, no.1 (2008): 49-55. Munting, Roger. 'The Games Ethic and Industrial Capitalism before 1914: the Provision of Company Sports'. Sport in History 23, no.1 (2003): 45-63.

Mussell, Bernard. Winchester Tennis and Squash Club: A Historical Record 1906-1992. The Club, 1994.

Nelson, J.V. A History of Hale Lawn Tennis Club. The Club, 2004.

Paish, Geoffrey L. Surrey County Lawn Tennis Association - the first 100 Years 1896-1996.

Brockham: the author, 1996.

Pinnock, Joe. Bedfordshire LTA - the First 75 Years. Bedfordshire Lawn Tennis Association, 1998.

Polley, Martin. Moving the Goalposts: a history of sport and society since 1945. London:

Routledge, 1998.

Putney Lawn Tennis Club Centenary Special 1879-1979. The Club, 1979.

Reigate Lawn Tennis Club Centenary 1906-2006. The Club, 2006.

Rivers, James, ed. The Sports Book, vols. 2 and 3. London: Macdonald \& Co., 1948, 1949.

Robertson, George. Tennis in Scotland: 100 Years of the Scottish Lawn Tennis Association 1895-1995. Edinburgh: Scottish Lawn Tennis Association, 1995.

Rockett, D.E. East Gloucestershire Tennis Club Centenary 1885-1985. The Club, 1985.

Sheffield \& District Lawn Tennis Association. Sheffield and District Lawn

Tennis Association: The first hundred years, 1889-1989. Sheffield: Sheffield \& District

Lawn Tennis Association, 1989.

Smyth, J.G. Lawn Tennis. London: B.T. Batsford, 1953.

Stell, Marion K. Half the Race: A History of Australian Women in Sport. North Ryde: Angus \&

Robertson, 1991.

Surbiton Lawn Tennis and Squash Rackets Club Centenary 1881-1981. The Club, 1981.

Tingay, Lance. History of Lawn Tennis in Pictures. London: Stacey, 1973.

Walker, Helen. 'Lawn Tennis'. In Sport in Britain: A Social History, ed. Tony Mason, 245-275.

Cambridge: Cambridge University Press, 1989.

Warwickshire County Lawn Tennis Association. Warwickshire LTA Handbook, 1966.

Williams, Jack. 'Churches, sport and identities in the North, 1900-1939'. In Sport and Identity in the North of England, eds. Jeff Hill and Jack Williams, 113-136. Keele: Keele University

Press, 1996. 